Article

\title{
An Investigation of Occupant Energy-Saving Behavior in Vernacular Houses of Behramkale (Assos)
}

\author{
Ebru Ergöz Karahan ${ }^{1, *}$, Özgür Göçer ${ }^{2}{ }^{\mathbb{D}}$, Kenan Göçer ${ }^{3}$ and Didem Boyacıŏglu ${ }^{3}$ \\ 1 Department of Architecture, Ozyegin University, Istanbul 34794, Turkey \\ 2 School of Architecture, Design and Planning, University of Sydney, Sydney 2006, Australia; \\ ozgur.gocer@sydney.edu.au \\ 3 Department of Architecture, Beykoz University, Istanbul 34805, Turkey; gocerkenan80@gmail.com (K.G.); \\ didemboyacioglu@gmail.com (D.B.) \\ * Correspondence: ebru.karahan@ozyegin.edu.tr
}

Citation: Karahan, E.E.; Göçer, Ö.;

Göçer, K.; Boyacıoğlu, D. An

Investigation of Occupant Energy-

Saving Behavior in Vernacular

Houses of Behramkale (Assos).

Sustainability 2021, 13, 13476.

https://doi.org/10.3390/su132313476

Academic Editor: Marco Lauteri

Received: 12 October 2021

Accepted: 23 November 2021

Published: 6 December 2021

Publisher's Note: MDPI stays neutral with regard to jurisdictional claims in published maps and institutional affiliations.

Copyright: (c) 2021 by the authors. Licensee MDPI, Basel, Switzerland. This article is an open access article distributed under the terms and conditions of the Creative Commons Attribution (CC BY) license (https:// creativecommons.org/licenses/by/ $4.0 /)$.
Abstract: Despite its well-known potential to reduce energy use, the inquiry of whether vernacular architecture prompts its occupants to have energy-saving behavior has been neglected. This paper aims to investigate the influence of vernacular houses on the behavior of their occupants and other parameters affecting occupant behavior. Along with site observations, 117 surveys including multiple choice and open-ended questions were conducted with households living in vernacular houses and new houses in the historical settlement, Behramkale (Assos). A principal component analysis was conducted for the whole sample to determine whether there is a relationship between energy saving occupant behavior and energy use, household, and housing characteristics. Then further analyses were performed to explore the differences in descriptive properties of occupants. Household characteristics were found to be associated with occupant behavior. The females and married people tended to show more energy-saving behavior and sought to use their houses in more environmentally friendly ways. The older people were more likely to show no-cost energysaving behavior. The households with high income and high-level education tended to invest in energy-efficient appliances but consumed more energy than other households. Besides the effects of household characteristics, historical heritage, and landscape values specific to the area influenced occupant behavior. Vernacular houses enabled the households to behave in a certain way and to continue the traditional daily habits related to sustainable, energy-saving behaviors.

Keywords: household energy use; household water use; occupant behavior; energy behavior; vernacular architecture; Mediterranean; Behramkale; Assos

\section{Introduction}

Extensive use of energy is one of the reasons for climate change, and the construction sector accounts for $40 \%$ of total energy use. In this picture, the residential sector (households) has contributed $25-27 \%$ to the total energy consumption since 1995 [1]. In this regard, the lack of climatic rationale in modern architecture and the role of households have drawn attention as an issue. In this context, learning from vernacular architecture can result in an effective model for sustainable architecture to maximize occupants' comfort with minimum energy and cost [2]. Vernacular architecture represents unique examples to specific regions, shows greater respect for the existing environment, and considers the constraints imposed by the climate [3]. Until the modern era, vernacular traditions that contain inherent, unwritten information about climate-responsive design and energy optimization have been transferred to the new generations by the local builders [4]. To ensure the continuation of knowledge transfer, many studies, for instance [2,5-9], are looking at how vernacular architecture design principles could be adapted to contemporary design to create sustainable environments. 
However, it is important to note that it is the people who use energy, not buildings [10], which makes the households and their energy-use behavior crucial. Occupant behavior (OB), defined by human-building interactions, impacts building energy use directly and indirectly [11]. A substantial body of literature demonstrates the importance of OB in the energy performance of buildings [12-18]. However, not much has been done to explore the impact of vernacular buildings on OB [19-22], even though vernacular architecture is widely accepted as an effective model for sustainable architecture [23]. Karahan [20-22] compared traditional houses with contemporary houses in one of the regions of Turkey in terms of both energy efficiency and OB. However, the area studied (Osmaneli, Turkey) has a significant level of deterioration because of renovations that have changed the characteristic vernacular architecture and affected the energy performance of the buildings. Wismayer et al. [19] highlighted the importance of documenting and conserving OB, which assimilates significant intangible social, environmental and identity values in heritage buildings. In addition, Heydarian et al. [24] found, in their review on occupant interactions with building systems, that these studies are conducted for a few countries and geographical locations such as United States, Western Europe, and China.

In this regard, the aim of this study is two-fold. Firstly, it addresses a gap in the existing knowledge base by exploring whether vernacular architecture as an effective model for sustainable architecture determines OB or not. Secondly, it attempts contribute to the number of studies related to $\mathrm{OB}$ in different geographical locations to understand the influence of geographical, climatic, cultural, and societal factors. An interrogation of a dataset of 117 surveys along with site observations has been conducted with households in the village of Behramkale, which includes two different settlements: the old settlement within its ancient walls and the new development area outside the walls. The setting affords a rare opportunity to analyze and compare OB in the vernacular (well-protected) and contemporary houses within the same context. By examining the dataset, this paper identifies key shared sources of $\mathrm{OB}$ and its interaction with housing and household features on energy and water use in a vernacular rural settlement. The main contributions to knowledge are:

- $\quad$ understanding the inherent potential of vernacular architecture in determining occupants' energy saving behavior,

- $\quad$ outlining occupant and housing related factors affecting OB in a settlement having rural characteristics of Mediterranean vernacular architecture.

The rest of this paper has been structured as follows: in Section 2, the literature on OB and related factors in energy use is reviewed, in Section 3, the methodology and the case study are explained, in Section 4, the study findings are introduced, in Section 5, the study findings are discussed, and finally, in Section 6, the conclusion is presented.

\section{Theoretical Background: Occupant Behavior, Energy and Water Use, and Factors Related to Occupant Behavior}

Even though new building standards and regulations, and improvements in materials and construction methods help to reduce energy use $[25,26]$, the contemporary way of life involves prominent levels of consumption-of energy, water, materials, and space $[27,28]$. This highlights the crucial role of OB, which significantly impacts the overall use of resources like energy and water $[14,29,30]$. OB can be explained as 'behaviors which a person in a room of a building, applies or does not apply to affect his/her personal interior environment' [31]. Different disciplines characterize 'behavior' as (i) adoption of energy technologies by the consumers (e.g., adaptation of thermal insulation, heating devices); (ii) the usage of energy-based technologies by the occupants (e.g., using the dishwasher); (iii) the requirements of the residents (e.g., hygiene, healthier environment); and (iv) the interaction of all these factors [32]. OB ranges from simple actions to more complicated ability-based attitudes [33]. Simple actions for environmental adaptation include opening a door or a window, controlling solar shading, using a fan, switching 
on and off, changing clothes, or drinking cold or hot beverages. Complicated behaviors require some understanding of complex building systems [34].

OB is affected by many factors, such as external factors (e.g., air temperature, the velocity of the wind, time of the day, orientation), personal factors (e.g., past experiences, attitude, choices), and building-related factors (such as ownership, appropriate heating devices, mechanical ventilation system) [35-38]. Fabi et al. [39] sorted the factors affecting OB into five categories: physical, environmental, contextual, psychological, and social factors. On the other hand, Wei et al. [40] grouped the factors as environmental (climate, indoor environment), factors based on building (building type, building area, heating system), factors based on occupant (age, sex, education level, household number, income, ownership, health), and other factors (time, awareness, and cost). Gill et al. [41] classified the factors as building-related and occupant-related factors. Based on their review analysis, Uddin et al. [13] found that personal (i.e., psychological, physiological), climatic (i.e., environmental, physical), occupant movement, building design, social, and economic criteria are the main features of $\mathrm{OB}$.

Many physical and psychological factors may determine OB, such as perceptions of comfort, homeownership [42], earnings [43], lifestyles, preferences, choices, habits, daily activities, individual background, and features of the household [35,44-47]. To consume less energy, besides retrofitting the housing features, it would be beneficial if the occupants developed energy-saving behavior [48]. Households' daily practices and routines that mean using less energy are accepted as occupants' energy-saving behaviors [49]. Occupants make daily decisions about energy-saving behaviors based on their habits, such as leaving the lights on or off, setting the washing machine cycle, or keeping the indoor heat at a certain level. Habits, lack of knowledge and perceptions of comfort create a barrier against energy-saving behavior [50]. In addition, the energy efficiency of the house has an impact on the habits related to setting the desired indoor temperature [51].

Building features, such as the envelope and heating-related technologies, have been proven to impact $\mathrm{OB}$ and energy use [52-54]. The size of the house, number of rooms [27,53,54], and construction type are significant influences [55] on energy use. For instance, Shipworth et al. [52] found that detached houses needed to be heated for longer to provide the same temperatures as mid-terrace houses. Hansen et al. [51] suggested that material arrangements, such as forms of technology or housing layout, have a notable influence on occupant expectations and practices. Linden et al. [56] reported that the residents of detached houses live with lower indoor temperatures than residents of apartments. Kane et al. [57], who analyzed six residential building types in terms of heating, also found that the average temperature of apartments was warmer than that of detached houses.

The influence of architectural design and the elements of color, geometry, and light on human behavior and perception has been broadly studied [58]. However, behavior related to energy consumption and architectural design has not received much attention. According to the reviewed research by Delzendeh et al. [59], many studies have focused on influential factors, such as environmental, physical, and personal factors, but the influence of architecture or design factors on OB has been overlooked. However, it has been suggested that designers can influence users with appropriate design strategies. For instance, the term "design for sustainable behavior" is advocated by product designers/researchers/practitioners [60-62] to lead users to behave sustainably in everyday life.

Moxon [63] advised that behavior such as conserving energy and water, cycling, and recycling can be made either effortless or inconvenient by basic architectural design decisions. Brown et al. [64] indicated that buildings with passive building strategies that require active occupant engagement can play a role in teaching occupants about energy and behavior. Casey [65] found that occupants of mud-brick dwellings could be positively linked with eco-centric attitudes. Daniel and Williamson's [66] findings supported these results. In her study of residents of buildings certified for Leadership in Energy and Environmental Design (LEED), Behbahani [67] found that the environmental performance of 
high-income LEED-certified multifamily housing was related to the building, the homes of the occupants, and the indoor and outdoor environmental behavior of the occupants. In the same study, several occupants of low-income LEED-certified multifamily housing revealed that their behaviors, such as conserving energy, shopping locally, and walking, came to them naturally because they had done them for so long (they adopted these behaviors before their current residence), and LEED played a minimal or indirect role in influencing residents' environmental behaviors. A study by Guerra Santin and Itard [68] showed similar results, as the households tended to continue their previous energy behaviors in their current houses. In summary, more research is needed to understand the influence of housing design in terms of vernacular architecture on $\mathrm{OB}$ and energy use.

Table 1 summarizes the papers reviewed focusing on subject, country, and building type. As seen in Table 1, research related to $\mathrm{OB}$ and housing features and research related to $\mathrm{OB}$ and vernacular buildings are very few. In this sense, this paper aims to contribute to the existing knowledge base by reporting findings from a survey study done in Turkey, which aimed at providing further understanding of whether vernacular architecture prompts their occupants to have energy-saving behavior.

Table 1. Reviewed papers related to OB and their focus, by country and building type.

\begin{tabular}{|c|c|c|c|}
\hline Topics & Researcher/s & Country & Building Type \\
\hline \multirow{8}{*}{$\begin{array}{c}\text { energy aspects } \\
\text { (energy efficiency, energy performance, } \\
\text { energy use) }\end{array}$} & {$[30,45]$} & Japan & \multirow{15}{*}{$\begin{array}{l}\text { Residential buildings (apartment, } \\
\text { terraced, detached, semi-detached } \\
\text { house or other) }\end{array}$} \\
\hline & {$[33,41,52]$} & UK & \\
\hline & [37] & Switzerland & \\
\hline & {$[34,54]$} & US & \\
\hline & {$[44,53,69]$} & Netherlands & \\
\hline & [56] & Sweden & \\
\hline & [66] & Australia & \\
\hline & {$[70,71]$} & Turkey & \\
\hline indoor \& outdoor environment & [34-36] & \multirow{2}{*}{ Denmark } & \\
\hline \multirow{4}{*}{ housing features } & [57] & & \\
\hline & [66] & Australia & \\
\hline & [67] & US & \\
\hline & [51] & UK & \\
\hline \multirow{2}{*}{$\begin{array}{l}\text { household, housing \& environment } \\
\text { features }\end{array}$} & [49] & UK & \\
\hline & {$[46]$} & Belgium & \\
\hline \multirow{2}{*}{ factors affecting $O B$} & [39] & worldwide & Residential or office buildings \\
\hline & [69] & China & Residential buildings \\
\hline \multirow{2}{*}{ energy performance } & [59] & \multirow{2}{*}{ worldwide } & \multirow{2}{*}{ residential or office buildings } \\
\hline & [14] & & \\
\hline household \& housing features & [20-22] & Turkey & \\
\hline ecological design parameters & [19] & Malta & \\
\hline \multirow{6}{*}{$\begin{array}{l}\text { energy aspects(energy efficiency, } \\
\text { energy performance, energy use) }\end{array}$} & [4] & worldwide & \\
\hline & [72] & Italy & \\
\hline & [73] & China & \\
\hline & [74] & Turkey & \\
\hline & {$[3,6,75]$} & India & \\
\hline & [76] & Iran & \\
\hline
\end{tabular}


Table 1. Cont.

\begin{tabular}{|c|c|c|c|}
\hline Topics & Researcher/s & Country & Building Type \\
\hline \multirow{5}{*}{ thermal performance \& comfort } & [19] & Malta & \multirow{11}{*}{ Vernacular houses } \\
\hline & [77] & China & \\
\hline & [78] & Nepal & \\
\hline & [79] & Iraq & \\
\hline & [80] & India & \\
\hline \multirow{6}{*}{$\begin{array}{l}\text { bioclimatic, ecological design } \\
\text { parameters }\end{array}$} & [2] & Palestine & \\
\hline & [5] & Iran & \\
\hline & [7] & Turkey & \\
\hline & [8] & worldwide & \\
\hline & [9] & Romania & \\
\hline & [81] & Spain & \\
\hline
\end{tabular}

\section{Materials and Methods}

The study is based on data collected in 2017 in Behramkale, Turkey. The data were collected through site observations and a survey, which included multiple choice and open-ended questions. The aim was to determine the influence of vernacular houses on the behavior of their occupants and to examine other housing and occupant related parameters affecting $\mathrm{OB}$.

There were 150 housing units in the old settlement and 104 in the new settlement, a total of 254 houses. Some of the housing units were either abandoned or used as summer houses [82]. According to 2017 census data [83], the population of the village was 678 . The survey yielded 125 questionnaires, of which 117 (46.0\% of the total houses) were selected to be analyzed in this paper. Most of the questionnaires were answered by one person living in the current residential building. Adults aged 18 and over participated in face-to-face interviews.

The surveys included (i) basic information about occupants' demographic characteristics, such as age, gender, and occupation, as well as (ii) information about their houses' features and (iii) the equipment and energy used, for instance heating, cooling, etc., and energy costs, and lastly (iv) occupants' energy behavior, i.e., willingness to save energy, opening windows, etc., as summarized in Table 2. The extended version of the questionnaire has been included in Appendix A.

Table 2. Questionnaire Items.

\begin{tabular}{cc}
\hline Key Categories & Questions \\
\hline Household Characteristics & $\begin{array}{c}\text { household size, age, education, occupation, income, } \\
\text { years spent in the house and in the village }\end{array}$ \\
\hline Housing Characteristics & Housing structure \\
\hline Energy Use & $\begin{array}{c}\text { Equipment used for heating and cooling, cooking and } \\
\text { lighting, energy costs }\end{array}$ \\
\hline Energy Behavior & $\begin{array}{c}\text { Ventilation, heating, opening windows, willingness to } \\
\text { save energy }\end{array}$ \\
\hline
\end{tabular}

The data were analyzed through statistical methods based on quantitative data. Statistical Package for the Social Sciences (SPSS) 24.0 was used for statistical analyses. First, Principal Component Analysis (PCA) was conducted for the whole sample to determine whether there is a relationship between $\mathrm{OB}$, energy use and household characteristics. Then further analyses, such as a one-way analysis of variance (ANOVA) and $t$-tests, were 
performed to explore the differences in descriptive properties of occupants such as gender, age, the settlement where they live, house income, etc. The outcomes of these analyses are introduced in Section 4: Results.

\section{Study Area: Behramkale (Assos)}

Behramkale village (formerly the ancient city of Assos) is in the southwestern part of the Biga Peninsula, $17 \mathrm{~km}$ south of the district of Ayvacık in the province of Çanakkale (Figure 1). It lies on a steep hill that rises $235 \mathrm{~m}$ above sea level and looks westward along the southern coastline of the Aegean Sea, eastward up to Mount Ida, and southward across the straits of Mytilene to the island of Lesbos [84]. The village epitomizes the rural characteristics of Mediterranean vernacular architecture, which is recognized for its climate-responsive vernacular strategies for passive cooling.

The earliest history of the settlement is thought to date back as far as the beginning of the first millennium BC [85]. The ancient city of Assos and the houses of Behramkale village were registered as an Urban Archaeological Site by the Superior Council of Immovable Antiquities and Monuments in 1982. After then, the construction of new buildings and even simple extensions was restricted. However, the villagers were allowed to construct new buildings outside the ancient city walls [82] in what was referred to as the new settlement.

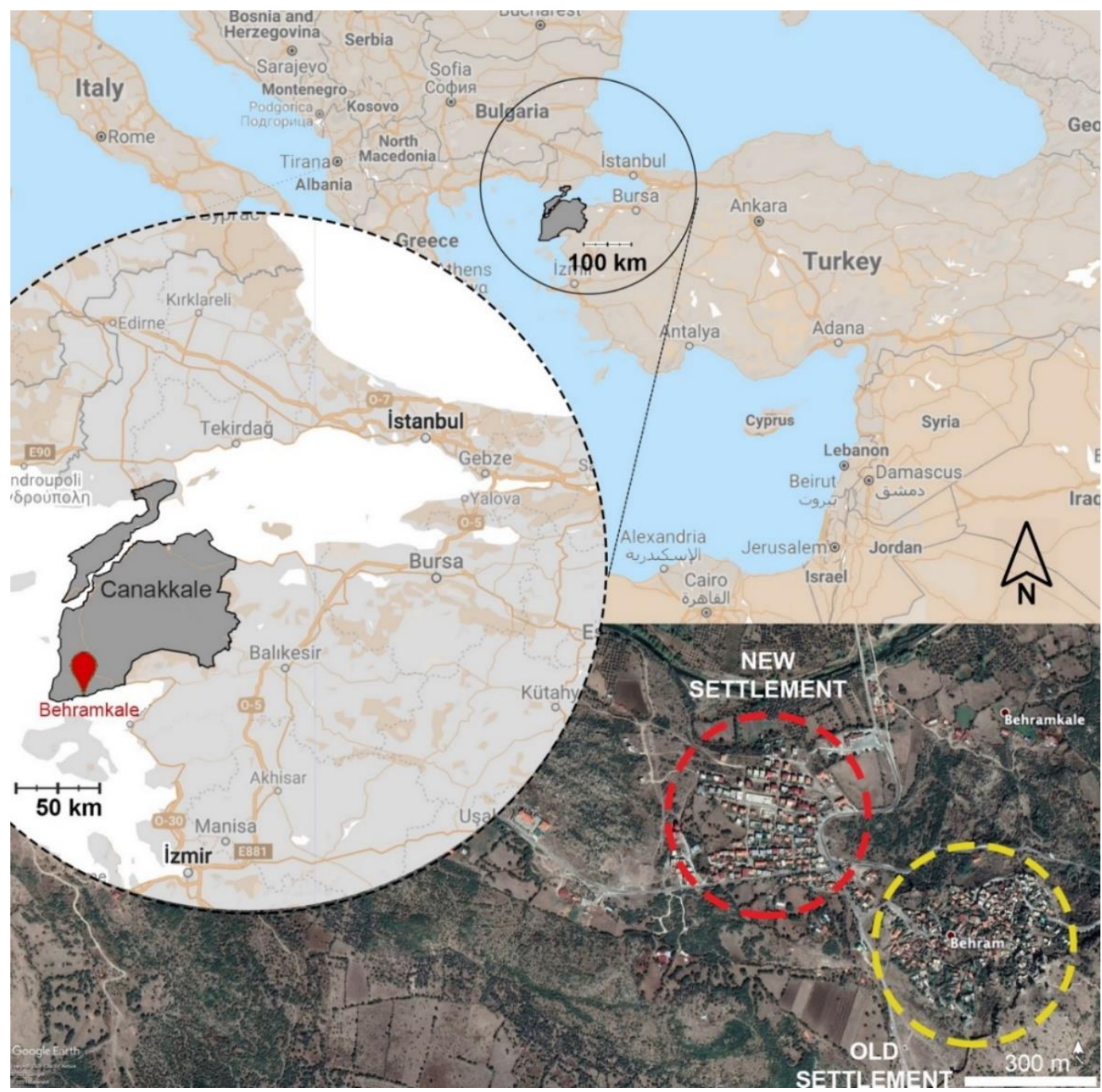

Figure 1. Behramkale (Ayvacık, Çanakkale) in Turkey.

The village comprises two settlements: the old settlement within the ancient city walls and the new settlement developed after 1982. The old settlement is located on the 
north-facing slope of the hill, out of sight of the sea. The new settlement area was planned in a grid pattern, unlike the old settlement, and was settled on the lower part of the hill (Figure 2).

The houses in the old settlement are compact with a square or rectangular shape with two or three rooms covering 50-60 $\mathrm{m}^{2}$. Masonry walls made of andesite stone are 70-100 cm thick, which act as a thermal mass, a climate-responsive strategy to cope with the hot, dry summers and cold winters. Walls 1.5-2.0 metres high surround courtyards that are the most active spaces of the houses, with green elements and water features. The courtyards contain separate toilets, and barns or storehouses and a hearth for cooking and a drinking fountain. The courtyard is the heart of the house since it is the main space for daily life activities, such as cooking, and social interactions because it cannot be seen from outside and has a comfortable thermal environment, open to the sky. Green elements in the courtyard play a significant role as a passive cooling approach during hot summer days (Figure 3). Houses are usually one or two stories and originally flat-roofed, but they have been changed into pitched roofs with terracotta tiles in recent renovations.

The new residential area is lower down the hill. The houses are usually two or more stories in height. The plots are mostly rectangular or square and are larger $\left(90-120 \mathrm{~m}^{2}\right)$ than the plots in the old settlement. Although there are some houses built with traditional methods in the village's new settlement, new buildings and extensions for traditional houses have been built with contemporary construction methods and materials in recent years (Figure 3). New houses have more and larger openings (the window to wall ratio is $30-45 \%$ ) without shading devices, making it difficult to control solar heat gains or losses and to conserve energy. Most of the houses have pitched roofs with terracotta tiles. Unlike the traditional courtyards, the gardens are used mostly for planting edible gardens, not for daily life activities. Since visual privacy is not required, the new houses do not have high courtyard walls, and instead they have terraces or balconies.

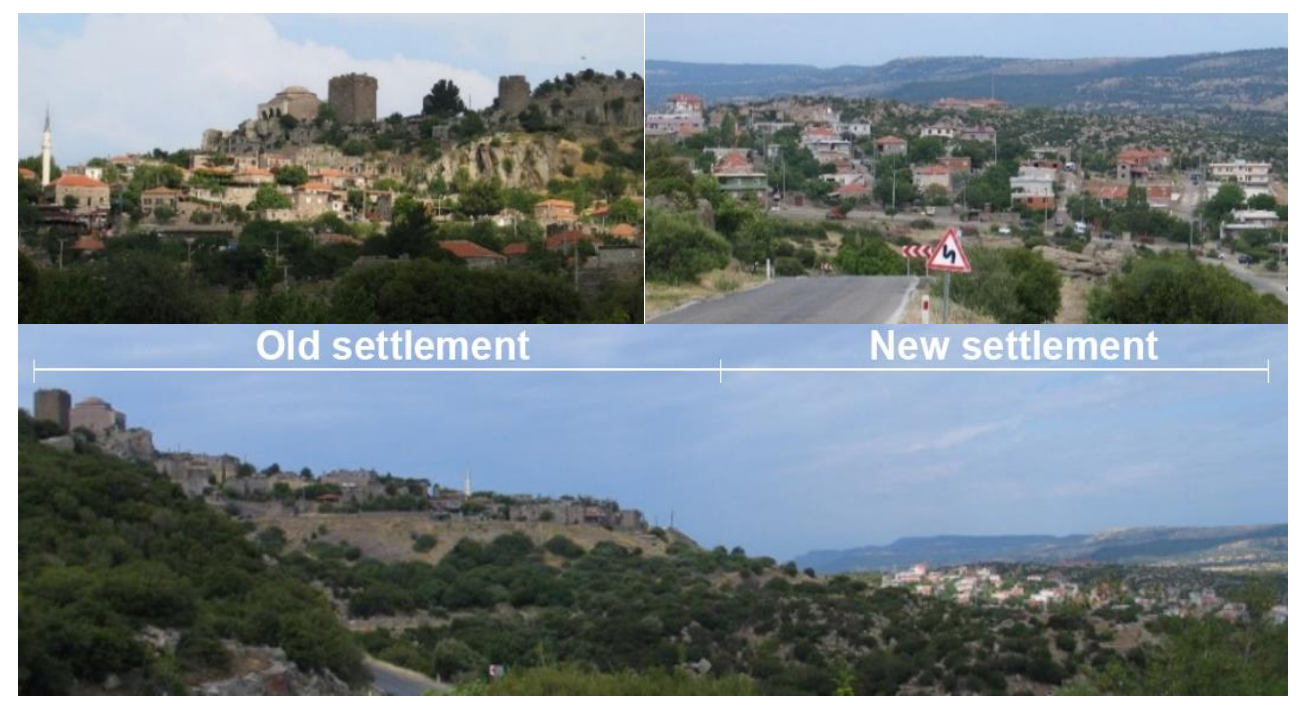

Figure 2. Behramkale Village, the old and the new settlements. 


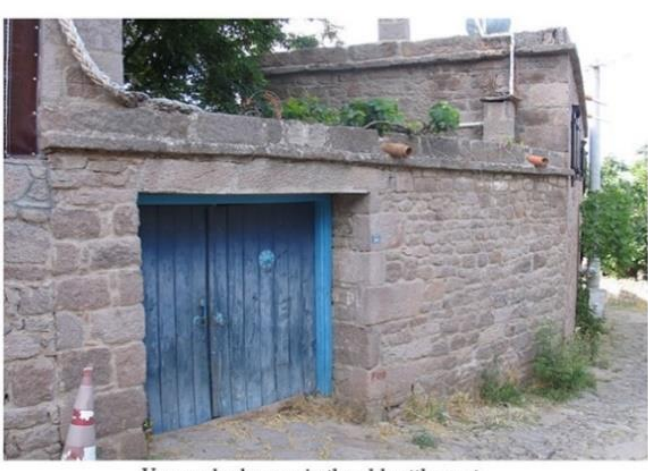

Vernacular houses in the old settlement

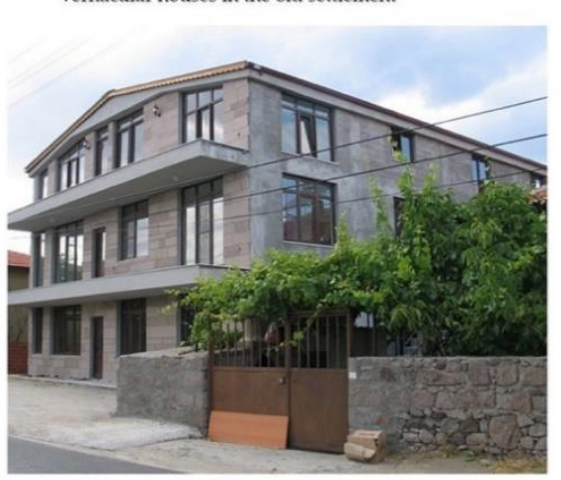

Houses in the new settlement
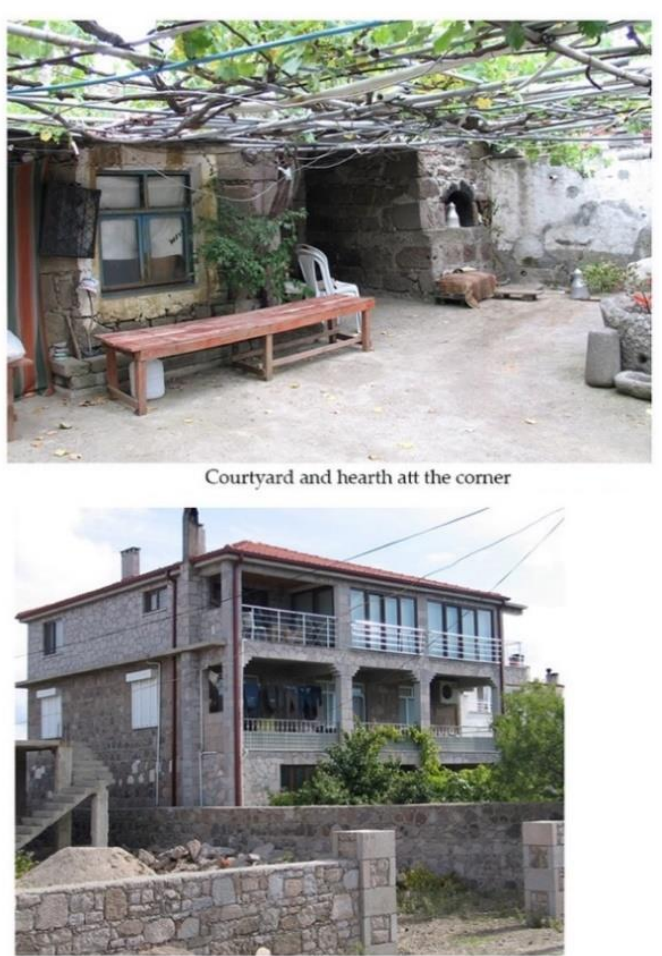

Figure 3. Vernacular and contemporary houses in the old and new settlements.

\section{Results}

\subsection{Household Characteristics}

Table 3 shows the descriptive statistics of household characteristics. Of the respondents who answered the survey, $78.6 \%$ lived in their houses throughout the year.

Table 3. Descriptive statistics of Household Characteristics.

\begin{tabular}{|c|c|c|c|c|c|}
\hline \multicolumn{2}{|c|}{ Household Characteristics } & \multirow{2}{*}{$\begin{array}{c}\% \\
75.2\end{array}$} & \multicolumn{2}{|c|}{ Household Characteristics } & $\%$ \\
\hline \multirow{3}{*}{ Household size } & 1-2 people & & \multirow{3}{*}{ Education level } & Elementary/middle & 64.9 \\
\hline & 3-4 people & 24.6 & & High school & 17.1 \\
\hline & $>4$ people & 0.02 & & University & 18.0 \\
\hline \multirow{4}{*}{ Monthly income } & $€ 160-200 *$ & 22.1 & \multirow{4}{*}{ Income type } & Self-employed & 36.8 \\
\hline & $€ 201-400$ & 40.7 & & Salary & 22.2 \\
\hline & $€ 401-1000$ & 28.3 & & Farmer & 19.6 \\
\hline & $>€ 1000$ & 8.8 & & Retirement pension & 21.4 \\
\hline \multirow{4}{*}{$\begin{array}{l}\text { Years spent in the } \\
\text { village }\end{array}$} & $0-10$ & 22.2 & \multirow{4}{*}{$\begin{array}{l}\text { Years spent in the } \\
\text { house }\end{array}$} & $0-10$ & 33.3 \\
\hline & $11-20$ & 8.5 & & $11-20$ & 20.5 \\
\hline & $21-40$ & 14.5 & & $21-40$ & 23.9 \\
\hline & $>40$ & 54.7 & & $>40$ & 22.2 \\
\hline \multirow{3}{*}{ Ownership } & Owner & 76.1 & \multirow{3}{*}{$\begin{array}{l}\text { Time spent in the } \\
\text { house during the year }\end{array}$} & Throughout the year & 78.6 \\
\hline & Tenant & 20.5 & & Spring and summer & 21.4 \\
\hline & Neither owner or tenant & 3.4 & & & \\
\hline
\end{tabular}


According to the survey data, $48.7 \%$ of the respondents were female, while $51.3 \%$ were male; $66.7 \%$ of them were married, and $43.6 \%$ were more than 55 years old. Except for two households with five members, the household sizes did not exceed four people. As to their education, $64.9 \%$ of the respondents were at the elementary or middle school level, while $17.9 \%$ had graduated from university; the rest were high school graduates. While $54.7 \%$ of the respondents had been living in the village for more than 40 years, $22.2 \%$ had lived in the same house for more than 40 years, $8.6 \%$ had lived in the same house since their birth, and $76 \%$ of the families owned their homes. The income level of the families was mostly between $€ 201$ and $€ 400$. Almost four-fifths (79.5\%) of the respondents were born and raised in the village. Three of the newcomers $(2.5 \%)$ were from a neighboring village, $7(6 \%)$ were from different counties of Çanakkale, and $14(12 \%)$ were from other cities in Turkey. Sixteen of the newcomers chose to live in the old settlement, and 14 of them were homeowners. Five of the respondents who were high school graduates were born in the village, whereas only two of the university graduates were from the village.

\subsection{Housing Characteristics, Occupant Behavior and Energy Use}

In the current study, 23\% of the houses examined were built between 1983 and 2007, $29 \%$ were built after 2007, and the rest were built before 1983 . Houses in the new settlement were built with either traditional or contemporary construction methods. In the first years after it was formed, the households who chose to live there built their homes using traditional construction methods and materials. The houses constructed with traditional methods usually included hearths in the courtyards, and 31 (25.6\%) of the houses used hearths for cooking. Six of these 31 hearths were in the newly built houses. Some houses ( $9.4 \%$ (of which $2 \%$ were old)) had thermal insulation; however, $25 \%$ of the households stated they intended adding thermal insulation.

Water use for $36.8 \%$ of the households was less than $15 \mathrm{~m}^{3} /$ month, and $56.4 \%$ used $15-30 \mathrm{~m}^{3} /$ month. Most of the households $(60.5 \%)$ who consumed water less than $15 \mathrm{~m}^{3} /$ month had houses smaller than $100 \mathrm{~m}^{2}$ and $79.0 \%$ of the households who had minimum water use per month were located in the old settlement (mean of the floor area of the houses is $85 \mathrm{~m}^{2}$ for this group). Of the households who had water consumption between 15 and $30 \mathrm{~m}^{3} /$ month, $63.8 \%$ resided in the old settlement. The mean of the houses' floor area in this group was $99.5 \mathrm{~m}^{2}$. Most of the households (55\%) who had water consumption more than $30 \mathrm{~m}^{3} /$ month resided in the new settlement and the mean of the floor area of the houses was $120 \mathrm{~m}^{2}$.

Electricity use for $27.4 \%$ of the households amounted to more than $240 \mathrm{kWh} / \mathrm{month}$, while $18.0 \%$ of the households who resided in old houses used less than $75 \mathrm{kWh} / \mathrm{month}$. Most of the houses (62.5\%) who consumed electricity more than $240 \mathrm{kWh} /$ month resided in the houses that were equal to or more than $100 \mathrm{~m}^{2}$.

As shown in Table 4, 63.3\% of the respondents used a coal stove, where the other households used a solid fuel combi boiler (CB) $(17.9 \%)$, air conditioner (AC) $(7.7 \%)$ or solar collector (SC) $(2.0 \%)$ for heating systems. One household used an AC and a SC, and one household used a CB and AC. Three households used AC and a stove together, and six houses did not have a heating system at all. Liquefied petroleum gas (LPG) (50.4\%), renewable energy sources $(25.6 \%)$ (Figure 4$)$, or electricity $(14.5 \%)$ were preferred for heating water. Usually, LPG or electricity was used for cooking. The households (26.5\%) who had hearths in their courtyards used them for cooking on firewood. AC was used by $37.3 \%$ of the households and, while 28 out of 47 households used it for 2-12 h daily, the rest used less than two hours daily. All of the households open their windows the whole year, except $22.2 \%$ of households who did not open windows during winter. 
Table 4. Descriptive statistics of Heating, Ventilation, Cooking and Hot Water.

\begin{tabular}{|c|c|c|c|c|c|}
\hline & Apparatus & $(\%)$ & & Apparatus & $(\%)$ \\
\hline \multirow{8}{*}{$\begin{array}{l}\text { Heating } \\
\text { System }\end{array}$} & Coal stove & 63.3 & \multirow{8}{*}{ Hot water } & Solar panels (SP) & 23.1 \\
\hline & $\mathrm{CB}$ & 18.0 & & Electricity & 12.0 \\
\hline & $\mathrm{AC}$ & 7.7 & & LPG & 43.6 \\
\hline & SC & 1.7 & & Solid fuel & 17.1 \\
\hline & Stove \& AC & 2.6 & & LPG \& electricity & 0.8 \\
\hline & SC \& CB & 0.8 & & SP \& electricity & 1.7 \\
\hline & $\mathrm{SC} \& \mathrm{AC}$ & 0.8 & & LPG \& SP & 0.8 \\
\hline & No heating system & 5.1 & & SP \& LPG \& electricity & 0.8 \\
\hline \multirow{3}{*}{$\begin{array}{l}\text { Cooling } \\
\text { System }\end{array}$} & Natural ventilation & 100 & \multirow{3}{*}{ Cooking } & LPG & 70.9 \\
\hline & $\mathrm{AC}$ & 37.3 & & Electricity & 2.6 \\
\hline & Ventilator & 37.6 & & LPG \& wood & 26.5 \\
\hline
\end{tabular}
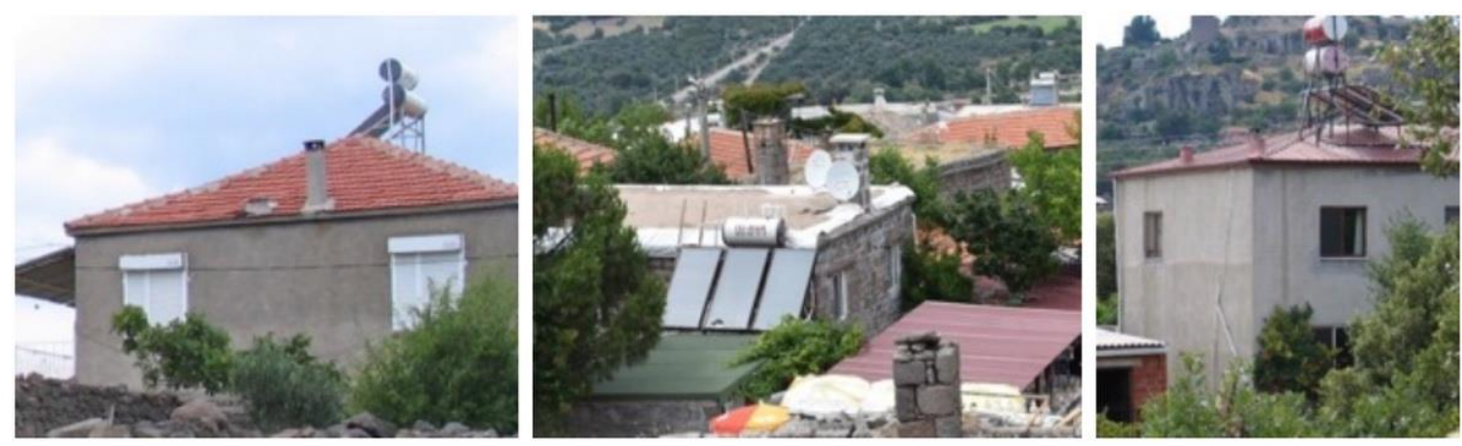

Figure 4. Use of Solar Collectors.

\subsection{Data Analysis}

A Principal Component Analysis (PCA) was used to identify factors underlying $\mathrm{OB}$, and the variables used in the analysis are shown in Table 5. Twenty-four variables were analyzed for the following factors: "devices and appliances", "space adaptation", "lighting", "water use", "personal adaptation", "comfort", "function", and "context".

Table 5. Behavior Factors and Factor Loadings Based on Principal Components Analysis of OB Variables $(n=117)$.

\begin{tabular}{|c|c|c|c|c|c|c|c|c|c|}
\hline \multirow{2}{*}{ Name of Factor } & \multirow{2}{*}{ Variables } & \multicolumn{8}{|c|}{ Component } \\
\hline & & 1 & 2 & 3 & 4 & 5 & 6 & 7 & 8 \\
\hline \multirow{4}{*}{ Device \& appliances (Factor 1) } & Preference of affordable appliances & 0.869 & & & & & & & \\
\hline & Use of energy saving appliances & 0.847 & & & & & & & \\
\hline & Use of energy-saving bulbs & 0.762 & & & & & & & \\
\hline & Thermal insulation & 0.702 & & & & & & & \\
\hline \multirow{3}{*}{ Space adaptation (Factor 2) } & Heat up during cold spells & & 0.819 & & & & & & \\
\hline & Use of curtain during hot spells & & 0.726 & & & & & & \\
\hline & $\begin{array}{l}\text { Disconnect the appliances when } \\
\text { they are off }\end{array}$ & & 0.629 & & & & & & \\
\hline \multirow[b]{2}{*}{ Lighting (Factor 3) } & Use natural light & & & 0.858 & & & & & \\
\hline & $\begin{array}{c}\text { Turn off the lights when it is not } \\
\text { used }\end{array}$ & & & 0.833 & & & & & \\
\hline
\end{tabular}


Table 5. Cont.

\begin{tabular}{|c|c|c|c|c|c|c|c|c|c|}
\hline \multirow{2}{*}{ Name of Factor } & \multirow{2}{*}{ Variables } & \multicolumn{8}{|c|}{ Component } \\
\hline & & 1 & 2 & 3 & 4 & 5 & 6 & 7 & 8 \\
\hline \multirow[t]{2}{*}{ Water use (Factor 4 ) } & $\begin{array}{l}\text { Second use of the wash water of } \\
\text { vegetables }\end{array}$ & & & & 0.866 & & & & \\
\hline & Second use of bathing water & & & & 0.798 & & & & \\
\hline Personal adaptation (Factor 5) & $\begin{array}{l}\text { Wear additional clothes during cold } \\
\text { spells }\end{array}$ & & & & & 0.95 & & & \\
\hline \multirow{6}{*}{ Comfort (Factor 6) } & House with less cost & & & & & & 0.705 & & \\
\hline & House having more natural light & & & & & & 0.683 & & \\
\hline & Use of outdoors & & & & & & 0.634 & & \\
\hline & Well-kept house & & & & & & 0.582 & & \\
\hline & Safety & & & & & & 0.564 & & \\
\hline & House design exposing wind & & & & & & 0.525 & & \\
\hline \multirow{4}{*}{ Function (Factor 7) } & $\begin{array}{c}\text { Enough number of rooms in the } \\
\text { house }\end{array}$ & & & & & & & 0.821 & \\
\hline & New house & & & & & & & 0.702 & \\
\hline & Functional house & & & & & & & 0.609 & \\
\hline & House easy to heat & & & & & & & 0.532 & \\
\hline \multirow{2}{*}{ Context (Factor 8) } & Historic value & & & & & & & & 0.808 \\
\hline & View & & & & & & & & 0.748 \\
\hline
\end{tabular}

The variables related to "Device \& appliances" (Factor 1) pointed to energy-concentrated use of appliances. The variables in "Space adaptation" (Factor 2) showed how occupants used the space and adapted it. The variables in "Lighting" (Factor 3) were related to lighting and point to a lifestyle more concerned with the use of natural light. The variables in "Water use" (Factor 4) indicated the use of water and showed a lifestyle with more concern for water. The variables in "Personal adaptation" (Factor 5) were related to personal adaptation; no variable had a high loading in this factor and the personal adaptation factor was independent of other types of behavior. The variables in "Comfort" (Factor 6) indicated the preference for a house to have a comfortable temperature. The variables in "Function" (Factor 7) were related to preference for a functional house; and the variables in "Context" (Factor 8) indicated values and preferences for an environment with a view and historical significance.

\subsection{Further Analyses of the Dataset}

One-way ANOVA test was used for categorical variables, and independent samples $t$-tests were applied for dichotomous variables.

The $t$-test analysis of Factors 3, 4, and 7 by gender found a statistically significant difference ( $p<0.05,95 \%$ confidence interval) (Table 6 ). The females were more likely to have energy-saving behaviors related to artificial and natural lighting and water use than males. The females tended to turn off the lights when they were not used, to use energy saving light bulbs, to use natural light rather than artificial light, to collect water and reuse it. Collecting and using the bathing water for the toilet and watering the plants with the water used for washing the vegetables were among the answers given for the reuse of water. The females tended to give more importance to the functionality and the spatial organization, having enough rooms in their homes and a better heating system.

The $t$-test analysis of Factor 8 by settlement found a statistically significant difference ( $p<0.05,95 \%$ confidence interval). The residents in the old settlement appeared to give value to the area and their housing more than the residents in the new settlement (Table 6). 
Table 6. $t$-test Result.

\begin{tabular}{|c|c|c|c|c|c|c|}
\hline Factor & & $n$ & Mean & $\begin{array}{c}\text { Std. } \\
\text { Deviation }\end{array}$ & $\begin{array}{l}\text { Std. Error } \\
\text { Mean }\end{array}$ & $\begin{array}{c}\text { Sig. } \\
\text { (2 Tailed) }(p)\end{array}$ \\
\hline \multirow{2}{*}{$\begin{array}{l}\text { Lighting } \\
\text { (Factor 3) }\end{array}$} & Female & 60 & 0.182 & 0.614 & 0.079 & \\
\hline & Male & 52 & -0.211 & 1.286 & 0.178 & 0.037 \\
\hline \multirow{2}{*}{$\begin{array}{l}\text { Water use } \\
\text { (Factor 4) }\end{array}$} & Female & 60 & 0.315 & 1.058 & 0.137 & \\
\hline & Male & 52 & -0.363 & 0.792 & 0.110 & 0.000 \\
\hline \multirow{2}{*}{$\begin{array}{l}\text { Function } \\
\text { (Factor 7) }\end{array}$} & Female & 61 & 0.265 & 0.926 & 0.118 & \\
\hline & Male & 56 & -0.289 & 1.005 & 0.134 & 0.002 \\
\hline \multirow{2}{*}{$\begin{array}{l}\text { Context } \\
\text { (Factor 8) }\end{array}$} & Old settlement & 62 & 0.407 & 0.774 & 0.0983 & \\
\hline & New settlement & 37 & -0.610 & 0.986 & 0.162 & 0.000 \\
\hline
\end{tabular}

One-way ANOVA test was performed to compare the frequency of behavior between diverse groups. Because some items had missing data, the summation of sample sizes in subgroups could not be equal to the total sample sizes. Statistically significant differences were found at the $p<0.05$ level. One-way ANOVA was conducted to determine differences in OB variables by household characteristics and energy use.

The households with a monthly income between $€ 401$ and $€ 1000$, married people, and the households with higher education tended to use more energy-saving appliances, energysaving light bulbs, affordable appliances, and thermal insulation than the households whose monthly income was less than $€ 400$, the households with single parents and the households with low education level. The household heads who were more than 65 years old were less likely to use or invest in energy-efficient appliances.

The households with a monthly income between $€ 401$ and $€ 1000$ and married people tended to heat the house during cold spells, use curtains during hot spells and disconnect the electricity of appliances when they are off more than the households with a monthly income between $€ 201$ and $€ 400$ and single parents. The households with a monthly income between $€ 401$ and $€ 1000$ tended to use the house more functionally, to have enough rooms and give more importance to the use of interior space than the households with a monthly income between $€ 160$ and $€ 200$ (Table 7).

The households with higher education and higher income tended to value heritage and landscape more and cared about them more than the households with the lowest monthly income and education level. The households with lower income also had lower education levels. The households that consumed modest energy for electricity tended to use more natural light and less artificial light. The households who used the maximum amount of water were mostly larger households and these households tended to search for a safe and well-kept house with less cost, more natural light and a courtyard. The households who used less water consisted of mostly one or two members. On the other hand, the amount of water use seen in the table also mostly reflects the amount of water used during summertime as the survey was realized during summer and the participants' answers were based on their recent water bills. During summer, the families with children used the beach more often, showered sometimes twice a day, and consumed more water (Table 8).

There was no significant correlation between marital status, ownership, age of the house, place of settlement, and energy use for electricity, heating, and water use. The households that did not use every room in the house during winter tended to pay less for heating. The households that used AC for heating had the biggest ratio of electric energy use. 
Table 7. Tukey Variance Test Results-Relationship Between OB and Household Characteristics.

\begin{tabular}{|c|c|c|c|c|c|}
\hline $\begin{array}{l}\text { Dependent } \\
\text { Variable }\end{array}$ & $\begin{array}{c}\text { Household } \\
\text { Characteristics }\end{array}$ & $\begin{array}{c}\text { Household } \\
\text { Characteristics }\end{array}$ & Mean Difference (I-J) & $\begin{array}{l}\text { Std. } \\
\text { Error }\end{array}$ & Sig. \\
\hline \multirow{6}{*}{$\begin{array}{c}\text { Device \& } \\
\text { appliances } \\
\text { Factor } 1\end{array}$} & $\begin{array}{l}\text { household monthly income } \\
€ 401-1000\end{array}$ & $\begin{array}{l}\text { hh. m. income } \\
\quad € 160-200\end{array}$ & 0.837 & 0.279 & 0.017 \\
\hline & married people & single parents & 0.588 & 0.237 & 0.039 \\
\hline & high education level & low education level & 1.009 & 0.274 & 0.005 \\
\hline & age $30-34$ & Age $>65$ & 1.318 & 0.350 & 0.005 \\
\hline & age $35-44$ & Age $>65$ & 1.382 & 0.294 & 0.000 \\
\hline & age $45-54$ & Age $>65$ & 1.100 & 0.279 & 0.003 \\
\hline \multirow{2}{*}{$\begin{array}{l}\text { Space adaptation } \\
\text { Factor } 2\end{array}$} & $\begin{array}{l}\text { hh. m. income } \\
\quad € 401-1000\end{array}$ & $\begin{array}{l}\text { hh. m. income } \\
\quad € 201-400\end{array}$ & 0.658 & 0.241 & 0.037 \\
\hline & married people & single parents & 0.634 & 0.236 & 0.023 \\
\hline $\begin{array}{l}\text { Function } \\
\text { Factor } 7\end{array}$ & $\begin{array}{l}\text { hh. m. income } \\
€ 401-1000\end{array}$ & $\begin{array}{l}\text { hh. m. income } \\
\quad € 160-200\end{array}$ & 0.711 & 0.271 & 0.049 \\
\hline \multirow{4}{*}{$\begin{array}{l}\text { Context } \\
\text { Factor } 8\end{array}$} & other financial sources & retirement pension income & 0.690 & 0.248 & 0.032 \\
\hline & $\begin{array}{l}\text { hh. m. income } \\
€ 401-1000\end{array}$ & $\begin{array}{l}\text { hh. m. income } \\
\quad € 160-200\end{array}$ & 0.903 & 0.265 & 0.005 \\
\hline & hh. m. income $>€ 1000$ & $\begin{array}{l}\text { hh. m. income } \\
\quad € 160-200\end{array}$ & 1.319 & 0.363 & 0.002 \\
\hline & high education level & low education level & 0.821 & 0.262 & 0.028 \\
\hline
\end{tabular}

Table 8. Tukey Variance Test Results-OB and Water and Electric Energy Use.

\begin{tabular}{|c|c|c|c|c|c|}
\hline $\begin{array}{l}\text { Dependent } \\
\text { Variable }\end{array}$ & Energy \& Water Use per Month & Energy \& Water Use per Month & $\begin{array}{l}\text { Mean Difference } \\
\text { (I-J) }\end{array}$ & $\begin{array}{l}\text { Std. } \\
\text { Error }\end{array}$ & Sig. \\
\hline Lighting Factor 3 & $\begin{array}{l}\text { Electric Energy Use (kWh/month) } \\
75-160\end{array}$ & $\begin{array}{l}\text { Electric Energy Use (kWh/month) } \\
160-240\end{array}$ & 0.794 & 0.300 & 0.046 \\
\hline Comfort Factor 6 & $\begin{array}{l}\text { Water use }\left(\mathrm{m}^{3} / \text { month }\right)<15 \\
\text { Water use }\left(\mathrm{m}^{3} / \text { month }\right)>30\end{array}$ & $\begin{array}{l}\text { Water use }\left(\mathrm{m}^{3} / \text { month) } 15-30\right. \\
\text { Water use }\left(\mathrm{m}^{3} / \mathrm{month}\right) 15-30\end{array}$ & $\begin{array}{l}0.691 \\
0.737\end{array}$ & $\begin{array}{l}0.239 \\
0.223\end{array}$ & $\begin{array}{l}0.024 \\
0.007\end{array}$ \\
\hline Function Factor 7 & Water use (m³ / month) 15-30 & Water use $\left(\mathrm{m}^{3} /\right.$ month $)>30$ & 0.783 & 0.285 & 0.034 \\
\hline
\end{tabular}

\section{Discussion}

The findings of the statistical analyses and site observations on $\mathrm{OB}$ and energy use are discussed in the following sections regarding household and housing characteristics.

\subsection{Household Characteristics and Occupant Behavior}

The statistical analyses determined differences in OB related to household characteristics such as gender, age, education level, income, and marital status regardless of where they lived. The descriptive statics of the household characteristics are listed in Section 4.1.

The respondents were asked questions regarding their use of electricity, domestic appliances, and energy-efficient appliances, and their habits for water use (such as bathing, laundry, and dishwashing), and cooking and heating. Gender was found to be statistically associated with energy-saving behavior (Table 6). Females used less artificial light, turned off lights when they were not using them, and used the water from washing vegetables and bathing afterward for other purposes. They preferred their houses to be larger, newer, easy to use, and easy to heat. Females were more concerned about saving energy and aimed for more environmentally friendly use of the houses. This finding reinforces other studies in the literature. Zhang et al. [69] also stated that gender has an effect on thermal 
and lighting behaviors. Mainieri et al. [86] and Olli et al. [87] found women to be more pro-environmental in their behavior (i.e., their actions are related to environmental improvement), and they are more likely to obtain energy-efficient appliances [49], and more inclined to save energy than men [88].

Older respondents $(>50)$ were more likely to show no-cost energy-saving behavior such as wearing additional clothes during cold spells. On the other hand, the household heads between 30 and 54 years old tended to use more energy-saving appliances than those who were more than 65 years old (Table 7). The reason for this might be that young respondents with families are positively related to energy-saving appliances. The other reason for the older household heads being less likely to invest in energy-efficient appliances may be that they lacked information on these appliances. This result is contradicted by Trotta [49] but in line with Poortinga et al. [89] and Nair et al. [90]. In the current study, the households who were in the "high education level" and "high income" categories consumed more energy for electricity than other households (Table 7). The households with higher education levels had opportunities to work for higher wages and could afford more appliances. The households who had thermal insulation also had higher incomes and higher education levels. Higher education was also related to more energy-saving behavior and investment in energy efficiency, such as thermal insulation. However, no difference was found between education levels for water use and the use of energy for heating.

Education level and energy-efficient technology adoption were found to be positively correlated [91,92]. Mills and Schleich [93] found that higher education levels, higher income, larger households, and higher electricity prices have a positive correlation with participants' knowledge about the energy efficiency label on appliances. No correlations were found between education level and energy behaviors by Pothitou et al. [94] and Olli et al. [87]. Findings by Vogiatzi et al. [95] overlap with our findings that people with higher education and married people are more related to energy-saving behavior. Barthelmes et al. [11] stated that electricity use is related to household size and changes accordingly. Gatersleben et al. [96] found that income, household size and housing energy use are related. Delzendeh et al. [59] reported that households with children were keen to use less energy. Guerra Santin [44] and Guerra Santin et al. [53] found that income was related to more energy consumption, but income and heating behavior did not correlate. Zhang et al. [69] did not find a significant correlation between higher income and more energy-efficient purchase behavior. Martinsson et al. [97] revealed that affluent households tend to use more energy than less well-off households in Sweden. Similarly, Trotta [49] found that low-income British households are more likely to save energy than middle-and high-income households. Vogiatzi et al. [95] discovered that low-income Greek households are more likely to realize no-cost energy-saving behaviors; however, in the current study, households that earned less tended not to use energy-saving appliances. The reason for this finding may be that energy-saving appliances are expensive for the households in this category, so they tend not to change their old appliances. As Yue et al. [98] expressed it, the ability to pay for energy-saving products and appliances is the key factor in acquiring energy-saving behavior.

In the current study, $58.2 \%$ of the respondents stated that they usually or always chose to wear additional clothes during cold spells, while $6.8 \%$ claimed they never wore additional clothes. Of those who wore extra clothes, $35.9 \%$ were more than 50 years old, and $71.4 \%$ of the university graduates were in this category. While $25.6 \%$ of the respondents reported that they never, or very rarely, increase heating setpoint during cold spells, $61.5 \%$ stated that they usually or always do. People who increased the heating setpoint $(62.5 \%)$ were less than 50 years old. Low-income occupants are more likely to show no-cost energy-saving behaviors rather than behaviors that they would have to pay for [67,95]. On the other hand, Hori et al. [99] found no correlation or a very weak correlation between income and energy-saving behavior in Chinese cities. Guerra Santin [44] argued that lower-income households are more likely to ventilate their homes than higher-income households. However, in our case, no difference was found in the use of natural ventilation 
by household and housing characteristics because all the households in both settlements used natural ventilation by opening windows and doors day and night in summer. During winter as well, most of the households $(77.8 \%)$ used natural ventilation.

Households who had a monthly income between $€ 401$ and $€ 1000$ tended to exhibit more energy-saving behavior than the households who had a monthly income between $€ 160$ and $€ 200$, and households in the higher income group tended to adapt their space according to the external conditions. The households who had more income and showed more energy-saving behavior also had a higher education level. In the current study, higher income was related to more electricity consumption but not to energy use for heating or water usage. Most of the newcomers $(90 \%)$ had higher income and higher education. It was observed that newcomers also adopted some behaviors of the households who were born in the village such as using the courtyard and using hearths in the courtyard. However, due to the contemporary lifestyle and working conditions, the use of electrical appliances was high.

The women who were at home during the day gathered to share the news or to help with food preparation or for religious activities. It was stated that unemployed or retired men were spending the day by gathering with their peers in a local cafe or/and the mosque. These gatherings enabled some of the households to use less energy for heating during winter.

The relationships between $\mathrm{OB}$ and households' socioeconomic characteristics, such as household composition, age, income, and education, have been widely studied in the literature. However, the findings related to household features can be ambivalent for many reasons, such as culture, so further research is needed.

\subsection{Housing Characteristics, Occupant Behavior and Energy Use}

Studies of vernacular architecture have focused on the investigation of unique characteristics of the buildings and the daily-life routine of users to interpret how buildings shape people, but determining their interaction with buildings has rarely been studied. However, as was mentioned by Salman [100], routine practices of people need to be investigated to grasp the essence of society's experience with the built and natural environment.

In this context, households' interaction with their houses and their use of windows for ventilation, curtains and/or shutters for sunlight, use of heating and cooling systems, use of their courtyards and rooms were searched via questions and site observations. Vernacular Behramkale houses present an optimum combination of "climatic building design", "the integration of building and courtyard for multiple purposes", "use of local materials", and "flexible use of space" for sustainable habitat. Passive design strategies of the buildings provide a comfortable indoor environment for their occupants by (i) building openings with sensible size and orientation, (ii) the thermal mass effect of the thick stone walls, and (iii) courtyards with greenery. Having strategies for passive cooling, the old houses in Behramkale are a good example of climate-responsive building design for Mediterranean climate zone.

The vernacular housing design in the settlement with compact shape, small and few openings with shading and high thermal mass, which stabilizes indoor temperature, creates a comfortable indoor climate, as most of the households (63.3\%) in the village did not have AC (Table 4). It was reported that $50 \%$ of people who had AC used it daily for less than two hours (half of the AC users were in the old settlement and $46.5 \%$ of the AC users were newcomers). The situation was remarkably similar for households that had ventilators. Due to our conversations with some respondents who had AC, one of the reasons for acquiring this appliance was due to the concern for summer heatwaves and warm spells. In addition, some households who used their houses as summer houses had concerns about keeping their guests comfortable via AC. All households tended to use curtains and shutters to avoid excessive heat gains.

Due to the mild weather in winter in the region, households could survive the winter and keep warm without much difficulty. Some of the houses used as summer houses were 
the main reason some households had no heating systems. Depending on the heating system or habits such as reserving the room for the guests, some households $(29.9 \%)$, most of whom lived in old houses ( $64 \%$ of this group), left at least one room unheated in winter.

Housing characteristics, such as floor area and thermal insulation, influenced energysaving behaviors [49] and energy use [53,54]. In the current study, because the floor areas of the houses were similar and there were very few $(9.4 \%)$ thermally insulated houses, it is not possible to draw a conclusion on these features. Two of these eleven houses were old houses. On the other hand, one-fourth of the households, $12.8 \%$ of whom lived in the old houses, reported that they would like to have thermal insulation. Some households $(17.9 \%)$ of the $12.8 \%$ who lived in old houses stated that they would like to add a room. A request for an extra room may be due to needing more comfort rather than the number of members in the family.

In this study, there were not any statistically significant differences in energy use of vernacular and new houses. On the other hand, the households who had the highest level of consumption in terms of water and electricity also resided in larger houses. Pertaining to the site observations and face to face interviews, it was seen that the design of vernacular houses enabled the local households to behave in a certain way and to continue the traditional daily habits related to sustainable, energy-saving behaviors. The households' energy saving habits and daily practices are listed below with the comparison of the house where they live:

- The households who were born in the village built their own homes either in the old settlement before 1982 or in the new settlement afterwards and mostly continued their habits. Although some effects of contemporary life were evident in their daily practices such as purchasing the foodstuff that they used to prepare at home before.

- It was observed that the newcomers adopted themselves to the old homes they resided in after some time they spent in the village as mentioned in Section 5.1.

- In the current study, the new and old houses differed in their use of courtyards. The courtyards of the vernacular houses were used intensively for various purposes such as cooking, eating, and daily activities. The high walls surrounding the courtyard and its green elements create a pleasant and comfortable microclimate, so users can spend the entire day performing various activities without using an appliance for cooling or lighting. For instance, households used plastic and/or metal bottles and cans as flowerpots. As the courtyards were full of plants in the old settlement, in the new settlement, the balconies or the courtyards of the new houses were not covered with plants as in the old settlement.

- Pertaining to our observations, the courtyards of the multi-story new houses that served more than one family were not actively used during the day, because since the courtyard did not belong to one family, the families did not feel comfortable using it freely. The surrounding wall did not obstruct the view of the courtyard from the street, which also indicates that privacy was not considered as an issue since the users were not spending time in the courtyard. The interaction of the spaces and courtyard was extremely limited; the entrance door of the house was the only opening to the courtyard, opposite the old houses.

- Some of the habitants of the new settlement stated that to enjoy the weather and/or the view they would visit the old settlement within the day and/or night more than the old settlement habitants who visited the new settlement.

- The majority of the households (86.3\%) admitted that the view and historical area, and $95 \%$ of the respondents admitted that the use of outdoors, was particularly important to them. Newcomers, households of the new and the old houses, used or preferred to use outdoors/courtyards.

- A few respondents (18.8\%), most of whom used AC (63.6\% of this group), stated that they would not need wind. Although all the households used natural ventilation, the respondents who stated this judgement were mostly less educated people (86.6\% of this group). 
- Some households (29.9\%), most of whom lived in old houses (64\% of this group), left at least one room unheated in winter. The heating system used in the old houses and the habits of the households shaped the way of heating, such as not heating some of the rooms.

- Use of energy-efficient appliances did not differ according to the housing features; however, as the households of the old houses were usually outdoors the frequency of using domestic appliances changed.

- The wood used in hearths and/or stoves were gathered from the woodlands in Ayvacik, the county.

\section{Conclusions}

Since the building occupants and their behavior are essential components of energy use in the built environment, research on the interaction between people and the built environment is important in developing new areas of architectural exploration. Since vernacular houses are good examples of climatic and energy-efficient design, they can be an inspiration to contemporary architecture under the pressure of climate change. Vernacular architecture also creates an optimum relationship with its occupants by its use of available local materials and technologies. For this reason, this paper purposes to determine the impact of vernacular houses on $\mathrm{OB}$ in a rural settlement, along with exploring the factors affecting OB, energy, and water use.

Household characteristics, such as gender, age, education level, income, and marital status, were found to be associated with OB. Households with higher education, married people and females exhibited more energy-saving behavior. The females and married people who tended to show more energy-saving behavior also sought more environmentally friendly usage of their houses. The older people were more likely to reveal no-cost energysaving behavior, although they were less likely to invest in energy-efficient appliances than their younger counterparts. The households with high income and high-level education tended to invest in energy-efficient appliances. Higher income households had more appliances, and they consumed more electricity than other households, but no correlation was found between higher income and energy use for heating or water usage. The households with low income tended to show no-cost energy-saving behaviors. No difference was found in the use of natural ventilation by household and housing characteristics as all the households in the village preferred natural ventilation.

It was also found that historical heritage and landscape values are determining factors of OB. We observed that the registration of the area as an Urban Archaeological Site impacted the awareness of its value. For instance, although most of the households in the village admitted the importance of the historic value of the area, the households living in the old settlement appreciated its historic value, and they were more likely to preserve their houses than the households living in the new settlement. The new residents of the village who resided in the old settlement adopted some behaviors of the local households such as using the courtyard and using hearths in the courtyard. The vernacular houses' passive design strategies provided residents with a comfortable indoor environment through building openings, thermal mass effect of thick stone walls, and green courtyards. The courtyards of the vernacular houses were used for various purposes where the courtyards of the new houses were not used as actively as the old ones. The design of vernacular houses enabled the households to behave in a certain way and to continue the traditional daily habits related to sustainable, energy-saving behaviors.

By extension, the findings of the occupants' interaction with the vernacular buildings will enrich the studies on this topic. Because of the complexities that underpin behavioral decisions, it is critical to gain a deeper knowledge of behavioral patterns and the elements that influence them. As some of the data of the study were obtained through observations and conversations with the households along with the survey, future research with more indepth interviews would be helpful to find out the factors behind energy-saving behaviors and their relationship with housing and household features. 
Author Contributions: Conceptualization, E.E.K. and Ö.G.; methodology, E.E.K. and Ö.G.; formal analysis, E.E.K. and K.G.; investigation, E.E.K., Ö.G. and D.B., data curation: E.E.K., Ö.G., K.G. and D.B.; visualization: E.E.K. and Ö.G.; writing-original draft preparation, E.E.K. and Ö.G.; writingreview and editing, E.E.K., Ö.G., K.G. and D.B. All authors have read and agreed to the published version of the manuscript.

Funding: This research received no external funding.

Institutional Review Board Statement: The study was conducted according to the guidelines of the Declaration of Helsinki, and approved by the Ethics Committee of Özyeğin University (2015/5, 27 August 2015).

Informed Consent Statement: Informed consent was obtained from all subjects involved in the study.

Acknowledgments: The authors would like to thank the students of Özyeğin University, Faculty of Architecture and Design who attended 2017 research internship for their contribution in collecting data.

Conflicts of Interest: The authors declare no conflict of interest.

\section{Appendix A}

Table A1. Questionnaire Items.

\begin{tabular}{|c|c|}
\hline Questions Related to Demography: & \\
\hline Gender of the participant & male, female, prefer not to say \\
\hline Age of the participant & $\ldots$ \\
\hline Marital status of the participant & married, single, widow, divorced, other \\
\hline Education level of the participant & elementary, middle school, high school, university \\
\hline Education level of the head of the household & $\ldots$ \\
\hline Place of birth & $\ldots$ \\
\hline The gender, education level and age of the household members & $\ldots$ \\
\hline Household head's occupation & $\ldots$ \\
\hline Household monthly income & $€ 160-200, € 201-400, € 401-1000,>€ 1000$ \\
\hline Income resources & $\ldots$ \\
\hline \multicolumn{2}{|l|}{$\begin{array}{l}\text { Questions related to Housing, Occupant Behavior and } \\
\text { Energy Use: }\end{array}$} \\
\hline The number of years spent in the village & $\ldots$ \\
\hline The place of residence before the current place & $\ldots$ \\
\hline The number of years spent in the current house & $\ldots$ \\
\hline House ownership & owner, tenant, neither owner nor tenant, other \\
\hline Duration of the residence in the house during the year & $\cdots$ \\
\hline $\begin{array}{c}\text { The number of rooms that are not used during summer or } \\
\text { winter } \\
\text { If the answer is yes, the reason for not using the rooms }\end{array}$ & $\cdots$ \\
\hline The frequency of opening the windows of the rooms & during winter: throughout the day, 5-6 h., 3-4 h., 1-2 h., never \\
\hline Ownership and use of Air Conditioner (AC) & night and day, throughout the day, 5-6 h., 3-4 h., 1-2 h., never \\
\hline Ownership and use of fan & night and day, throughout the day, 5-6 h., 3-4 h., 1-2 h., never \\
\hline Energy saving behaviors & $\begin{array}{c}\text { Such as using daily light, turning off the lights, frequency of } \\
\text { using washing/dish machines, wearing additional clothes } \\
\text { during cold spells... }\end{array}$ \\
\hline Water saving behaviors & $\begin{array}{l}\text { Such as use of bathing water, frequency of bathing, watering the } \\
\text { plants with the water used for washing the vegetables }\end{array}$ \\
\hline
\end{tabular}


Table A1. Cont.

Questions related to Housing, Occupant Behavior and Energy Use:

\begin{tabular}{|c|c|}
\hline Heating System & $\begin{array}{l}\text { Coal stove, Combi Boiler (CB), AC, Solar collector (SC), Stove \& } \\
\text { AC, SC \& CB, SC \& AC, No heating system }\end{array}$ \\
\hline Cooling system & Natural ventilation, AC, Ventilator \\
\hline Cooking & LPG, electricity, LPG \& wood \\
\hline Hot water & $\begin{array}{l}\text { Solar panels (SP), Electricity, LPG, Solid fuel, LPG \& electricity, } \\
\text { SP \& electricity, LPG \& SP, SP \& LPG \& electricity }\end{array}$ \\
\hline Ownership and frequency of use of electrical devices & $\begin{array}{l}\mathrm{TV} \text {, computer, washing machine, dish washer, dryer, deep } \\
\text { freezer, vacuum cleaner, AC, fan, toaster, kettle, microwave }\end{array}$ \\
\hline Ownership of the energy saving products & $\ldots \ldots$ \\
\hline Presence of thermal insulation & $\ldots \ldots$ \\
\hline Cost of heating per month & $\ldots \ldots$ \\
\hline Cost of hot water per month & $\ldots \ldots$ \\
\hline Cost of electricity per month & $\ldots \ldots$ \\
\hline \multicolumn{2}{|l|}{ Open ended questions: } \\
\hline \multicolumn{2}{|c|}{ The most important and valued feature of the participant's house according to him/her } \\
\hline \multicolumn{2}{|c|}{ Use of the house during a day/night } \\
\hline \multicolumn{2}{|c|}{ How a day is spent in the village } \\
\hline
\end{tabular}

Foodstuff made in the house (such as bread, preserves, jam, dried vegetables/fruit)

The most important thing for the village now and in the future according to the participant and the reason for that (such as tourism, agriculture, heritage, industry)

The most important value in participant's life (such as friends, village, nature, family, career, income)

\section{References}

1. Eurastat. 2021. Available online: https://ec.europa.eu/eurostat/statistics-explained/index.php?title=Energy_consumption_ in_households\&oldid=488255 (accessed on 5 May 2021).

2. Tawayha, F.A.; Braganca, L.; Mateus, R. Contribution of the vernacular architecture to the sustainability: A comparative study between the contemporary areas and the old quarter of a Mediterranean city. Sustainability 2019, 11, 896. [CrossRef]

3. Singh, M.K.; Mahapatra, S.; Atreya, S.K. Bioclimatism and vernacular architecture of north-east India. Build. Environ. 2009, 44, 878-888. [CrossRef]

4. Zhai, Z.J.; Previtali, J.M. Ancient vernacular architecture: Characteristics categorization and energy performance evaluation. Energy Build. 2010, 42, 357-365. [CrossRef]

5. Motealleh, P.; Zolfaghari, M.; Parsaee, M. Investigating climate responsive solutions in vernacular architecture of Bushehr city. HBRC J. 2018, 14, 215-223. [CrossRef]

6. Chandel, S.S.; Sharma, V.; Marwah, B.M. Review of Energy Efficient Features in Vernacular Architecture for Improving Indoor Thermal Comfort Conditions. Renew. Sustain. Energy Rev. 2016, 65, 459-477. [CrossRef]

7. Kırbaş, B.; Hızlı, B. Learning from Vernacular Architecture: Ecological Solutions in Traditional Erzurum Houses. Procedia Soc. Behav. Sci. 2016, 216, 788-799. [CrossRef]

8. Weber, W.; Yannas, S. (Eds.) . Lessons from Vernacular Architecture; Routledge: Oxfordshire, UK, 2013.

9. Creangă, E.; Ciotoiu, I.; Gheorghiu, D.; Nash, G. Vernacular Architecture as A Model for Contemporary Design. WIT Trans. Ecol. Environ. 2010, 128, 157-171. [CrossRef]

10. Janda, K.B. Buildings don't use energy: People do. Archit. Sci. Rev. 2011, 54, 15-22. [CrossRef]

11. Barthelmes, V.M.; Becchio, C.; Corgnati, S.P. Occupant behavior lifestyles in a residential nearly zero energy building: Effect on energy use and thermal comfort. Sci. Technol. Built Environ. 2016, 22, 960-975. [CrossRef]

12. Chen, S.; Zhang, G.; Xia, X.; Chen, Y.; Setunge, S.; Shi, L. The impacts of occupant behavior on building energy consumption: A review. Sustain. Energy Technol. Assess. 2021, 45, 101212. [CrossRef]

13. Uddin, M.N.; Wei, H.H.; Chi, H.L.; Ni, M. Influence of Occupant Behavior for Building Energy Conservation: A Systematic Review Study of Diverse Modeling and Simulation Approach. Buildings 2021, 11, 41. [CrossRef] 
14. Balvedi, B.F.; Ghisi, E.; Lamberts, R. A review of occupant behaviour in residential buildings. Energy Build. 2018, 174, 495-505. [CrossRef]

15. Yan, D.; Hong, T. IEA-EBC Annex 66, Definition and Simulation of Occupant Behavior in Buildings; Annex 66 Final Report May 2018; EBC Bookshop: Birmingham, UK, 2018.

16. Zhang, Y.; Bai, X.; Mills, F.M.; Pezzey, J.C.M. Rethinking the role of occupant behavior in building energy performance: A review. Energy Build. 2018, 172, 279-294. [CrossRef]

17. Yousefia, F.; Gholipoura, Y.; Yanba, W. A study of the impact of occupant behaviors on energy performance of building envelopes using occupants' data. Energy Build. 2017, 148, 182-198. [CrossRef]

18. Dong, B.; Li, Z.; Mcfadden, G. An investigation on energy-related occupancy behavior for low-income residential buildings. Sci. Technol. Built Environ. 2015, 21, 892-901. [CrossRef]

19. Wismayer, A.; Hayles, C.S.; McCullen, N. The role of education in the sustainable regeneration of built heritage: A case study of Malta. Sustainability 2019, 11, 2563. [CrossRef]

20. Karahan, E.E. Evaluation of Traditional Turkish Housing in Context of Energy Efficiency and Occupant Behavior. In Proceedings of the ENHR (European Network for Housing Research) 2014 Beyond Globalisation: Remaking Housing Policy in a Complex World, Edinburgh, UK, 1-4 July 2014.

21. Karahan, E.E. A Comparison of the Traditional with the Contemporary Turkish Housing in Context of Energy Efficiency and Occupancy Behavior. In Proceedings of the ENHR (European Network for Housing Research) 2015 Housing and Cities in a Time of Change: Are We Focusing on People? Lisbon, Portugal, 29 June-1 July 2015.

22. Karahan, E.E. Daily Life and Sustainability in Today's and Traditional Housing: Case of Osmaneli. Megaron 2017, 12, 497-510. (In Turkish) [CrossRef]

23. Nguyen, A.T.; Truong, N.S.H.; Rockwood, D.; Le, A.D.T. Studies on sustainable features of vernacular architecture in different regions across the world: A comprehensive synthesis and evaluation. Front. Archit. Res. 2019, 8, 535-548. [CrossRef]

24. Heydarian, A.; McIlvennie, C.; Arpan, L.; Yousefi, S.; Syndicus, M.; Schweikere, M.; Jazizadeh, F.; Rissetto, R.; Pisello, A.L.; Piselli, C.; et al. What drives our behaviors in buildings? A review on occupant interactions with building systems from the lens of behavioral theories. Build. Environ. 2020, 179, 106928. [CrossRef]

25. Beerepoot, M.; Beerepoot, N. Government Regulations as an Impetus for Innovations Evidence for Energy Performance Regulation in the Dutch Residential Building Sector. Energy Policy 2007, 35, 4812-4825. [CrossRef]

26. Leth-Petersen, S.; Togeby, M. Demand for Space Heating in Apartment Blocks: Measuring Effect of Policy Measures Aiming at Reducing Energy Consumption. Energy Econ. 2001, 23, 387-403. [CrossRef]

27. European Environment Agency (EEA). 2021. Available online: https://www.eea.europa.eu/data-and-maps/indicators/progresson-energy-efficiency-in-europe-3/assessment (accessed on 5 May 2021).

28. Lutzenhiser, L.; Hill Gossard, M. Lifestyle, Status and Energy Consumption, Panel 8. Consumer Behavior and Non-Energy Effects, ACEEE Buildings Conference. 2000. Available online: https://www.eceee.org/library/conference_proceedings/ACEEE_ buildings/2000/Panel_8/p8_17/(accessed on 5 May 2021).

29. Mahdavi, A.; Mohammadi, A.; Kabir, E.; Kambeva, L. Occupants' operation of lighting and shading systems in office buildings. J. Build. Perform. Simul. 2008, 1, 57-65. [CrossRef]

30. Yu, Z.; Fung, B.C.M.; Haghighat, F.; Yoshino, H.; Morofsky, E. A systematic procedure to study the influence of occupant behavior on building energy consumption. Energy Build. 2011, 43, 1409-1417. [CrossRef]

31. Hoes, P.; Hensen, J.L.M.; Loomans, M.G.L.C.; de Vries, B.; Bourgeois, D. User Behavior in Whole Building Simulation. Energy Build. 2009, 41, 295-302. [CrossRef]

32. Keirstead, J. Evaluating the Applicability of Integrated Domestic Energy Consumption Frameworks in the UK. Energy Policy 2006, 34, 3065-3077. [CrossRef]

33. Wood, G.; Newborough, M. Dynamic Energy Consumption Indicators for Domestic Appliances: Environment, Behavior and Design. Energy Build. 2003, 35, 821-841. [CrossRef]

34. Langevin, J.; Gurian, P.L.; Wen, J. Reducing Energy Consumption in Low Income Public Housing: Interviewing Residents about Energy Behaviors. Appl. Energy 2013, 102, 1358-1370. [CrossRef]

35. Andersen, R.V.; Toftum, J.; Andersen, K.K.; Olesen, B.W. Survey of occupant behaviour and control of indoor environment in Danish dwellings. Energy Build. 2009, 41, 11-16. [CrossRef]

36. Andersen, R.V.; Olesen, B.W.; Toftum, J. Modelling occupants' heating set-point preferences. In Proceedings of the 12th International Building Performance Simulation Association, Sydney, NSW, Australia, 14-16 November 2011; pp. 14-16.

37. Carneiro, J.P.; Aryal, A.; Becerik-Gerber, B. Understanding the influence of orientation, time-of-day and blind use on user's lighting choices and energy consumption using immersive virtual environments. Adv. Build. Energy Res. 2021, 15, 603-629. [CrossRef]

38. Yang, S.; Pernot, J.G.; Jorin, C.H.; Niculita-Hirzel, H.; Perret, V.; Licina, D. Energy, indoor air quality, occupant behavior, self-reported symptoms and satisfaction in energy-efficient dwellings in Switzerland. Build. Environ. 2020, 171, 106618. [CrossRef]

39. Fabi, V.; Andersen, R.V.; Corgnati, S.; Olesen, B.W. Occupants' Window Opening Behaviour: A Literature Review of Factors Influencing Occupant Behaviour and Models. Build. Environ. 2012, 58, 188-198. [CrossRef]

40. Wei, S.; Jones, R.; Wilde, P. Driving factors for occupant-controlled space heating in residential buildings. Energy Build. 2014, 70, 36-44. [CrossRef] 
41. Gill, Z.M.; Tierney, M.J.; Pegg, I.M.; Allan, N. Low-Energy Dwellings: The Contribution of Behaviours to Actual Performance. Build. Res. Inf. 2010, 38, 491-508. [CrossRef]

42. Sardianou, E. Estimating space heating determinants: An analysis of Greek households. Energy Build. 2008, 40, 1084-1093. [CrossRef]

43. Burney, N.A. Socioeconomic Development and Electricity Consumption. A Cross-Country Analysis Using the Random Coefficient Method. Energy Econ. 1995, 17, 185-195. [CrossRef]

44. Guerra Santin, O. Behavioural Patterns and User Profiles Related to Energy Consumption for Heating. Energy Build. 2011, 43, 2662-2672. [CrossRef]

45. Schweiker, M.; Shukuya, M. Comparison of Theoretical and Statistical Models of Air-Conditioning-Unit Usage Behaviour in a Residential Setting under Japanese Climatic Conditions. Build. Environ. 2009, 44, 2137-2149. [CrossRef]

46. Verbruggen, S.; Delghust, M.; Laverge, J.; Janssens, A. Evaluation of the relationship between window use and physical environmental variables: Consistency, seasonality and diversity. J. Build. Perform. Simul. 2021, 14, 366-382. [CrossRef]

47. Dominguez, C.; Orehounig, K.; Carmeliet, J. Estimating hourly lighting load profiles of rural households in East Africa applying a data-driven characterization of occupant behavior and lighting devices ownership. Dev. Eng. 2021, 6, 100073. [CrossRef]

48. Ding, Z.H.; Li, Y.Q.; Zhao, C.; Liu, Y.; Li, R. Factors affecting heating energy-saving behavior of residents in hot summer and cold winter regions. Nat. Hazards 2019, 95, 193-206. [CrossRef]

49. Trotta, G. Factors affecting energy-saving behaviours and energy efficiency investments in British households. Energy Policy 2018, 114, 529-539. [CrossRef]

50. Huebner, G.M.; Cooper, J.; Jones, K. Domestic Energy Consumption-What Role Do Comfort, Habit and Knowledge About the Heating System Play? Energy Build. 2013, 66, 626-636. [CrossRef]

51. Hansen, A.R.; Gram-Hanssen, K.; Knudsen, H.N. How building design and technologies influence heat-related habits. Build. Res. Inf. 2018, 46, 83-98. [CrossRef]

52. Shipworth, M.; Firth, S.K.; Gentry, M.I.; Wright, A.J.; Shipworth, D.T.; Lomas, K.J. Central heating thermostat settings and timing: Building demographics. Build. Res. Inf. 2009, 38, 50-69. [CrossRef]

53. Guerra Santin, O.; Itard, L.; Visscher, H. The effect of Occupancy and Building Characteristics on Energy Use for Space and Water Heating in Dutch Residential Stock. Energy Build. 2009, 41, 1223-1232. [CrossRef]

54. Steemers, K.; Yun, G.Y. Household energy consumption: A study of the role of occupants. Build. Res. Inf. 2009, 37, 625-637. [CrossRef]

55. Australian Bureau of Statistics. Environmental Issues: Energy Use and Conservation. 4602.0.55.001. 2008. Available online: https:/ / www.abs.gov.au/AUSSTATS/abs@.nsf/Lookup/4602.0.55.001Main+Features1Mar\%202008 (accessed on 6 May 2021).

56. Linden, A.; Carlsson-Kanyama, A.; Eriksson, B. Efficient and Inefficient Aspects of Residential Energy Behavior: What Are the Policy Instruments for Change. Energy Policy 2006, 34, 1918-1927. [CrossRef]

57. Kane, T.; Firth, S.K.; Lomas, K.J. How are UK homes heated? A city-wide, socio-technical survey and implications for energy modelling. Energy Build. 2015, 86, 817-832. [CrossRef]

58. Caan, S. Rethinking Design and Interiors, Human Beings in the Built Environment; Laurence King: London, UK, 2011.

59. Delzendeh, E.; Wua, S.; Leea, A.; Zhou, Y. The impact of occupants' behaviours on building energy analysis: A research Review. Renew. Sustain. Energy Rev. 2017, 80, 1061-1071. [CrossRef]

60. De Medeiros, J.F.; Da Rocha, C.G.; Ribeiro, J.L.D. Design for sustainable behavior (DfSB): Analysis of existing frameworks of behavior change strategies, experts' assessment and proposal for a decision support diagram. J. Clean. Prod. 2018, 188, 402-415. [CrossRef]

61. Lilley, D.; Wilson, G.; Bhamra, T.; Hanratty, M.; Tang, T. Design Interventions for Sustainable Behavior in Design for Behavior Change: Theories and Practices of Designing for Change; Niedderer, K., Clune, S., Ludden, G., Eds.; Routledge: Oxfordshire, UK, 2017.

62. Wilson, G.T.; Bhamra, T.; Lilley, D. Evaluating Feedback Interventions: A Design for Sustainable Behaviour Case Study. Int. J. Des. 2016, 10, 87-99.

63. Moxon. S. Sustainability in Interior Design; Laurence King: London, UK, 2012.

64. Brown, Z.B.; Dowlatabadi, H.; Cole, R.J. Feedback and Adaptive Behaviour in Green Buildings. Intell. Build. Int. 2009, 1, 296-315. [CrossRef]

65. Casey, P. People Who Live in Mudbrick Houses Aren't Simply Clones: The Motives, Environmental Behaviour and Environmental Attitudes of Muddies'. In Proceedings of the Earth Conference, Sydney, NSW, Australia, 19-20 January 2005.

66. Daniel, L.; Williamson, T. A study of the user behaviours in dwellings of earth construction, ANZAScA 2011: From principles to practice in architectural science. In Architecture Publications Aurora Harvest, Proceedings of the 45th Annual Conference of the Australian and New Zealand Architectural Science Association, Sydney, NSW, Australia, 16-18 November 2011; Hyde, R., Hayman, S., Cabrera, D., Eds.; 2011; pp. 1-8.

67. Behbehani, L.J. Does LEED-Certified Multifamily Housing Influence Occupants' Environmental Behaviors? Case Studies of Housing Developments in the Midwest. Ph.D. Thesis, Purdue University Graduate School, West Lafayette, IN, USA, 2012.

68. Guerra Santin, O.; Itard, L. Occupant Behaviour: Determinants and Effects on Residential Heating Consumption. Build. Res. Inf. 2010, 38, 318-338. [CrossRef]

69. Zhang, Y.; Xuemei Bai, X.; Mills, F.P. Characterizing energy-related occupant behavior in residential buildings: Evidence from a survey in Beijing, China. Energy Build. 2020, 214, 109823. [CrossRef] 
70. Harputlugil, G.U.; Harputlugil, T. A research on occupant behaviour pattern of dwellings in the context of environmental comfort and energy saving. J. Fac. Eng. Archit. Gazi Univ. 2016, 31, 695-708.

71. Harputlugil, G.U.; Harputlugil, T.; Pedergnana, M.; Sarığlu, E. A novel approach for renovation of current social housing stock based on energy consumption in Turkey: Significance of occupant behaviour. Archit. Sci. Rev. 2019, 62, 323-337. [CrossRef]

72. Cardinale, N.; Micucci, M.; Ruggiero, F. Analysis of Energy Saving Using Natural Ventilation in a Traditional Italian Building. Energy Build. 2003, 35, 153-159. [CrossRef]

73. Renping, W.; Zhenyu, C. An ecological assessment of the vernacular architecture and of its embodied energy in Yunnan, China. Build. Environ. 2006, 41, 687-697. [CrossRef]

74. Yüksek, İ.; Esin, T. Analysis of traditional rural houses in Turkey in terms of energy efficiency. Int. J. Sustain. Energy 2013, 32, 643-658. [CrossRef]

75. Shukla, A.; Tiwari, G.N.; Sodha, M.S. Embodied energy analysis of adobe house. Renew. Energy 2009, 34, 755-761. [CrossRef]

76. Mohammadzadeh, E.; Akhavan Farshchi, M.; Ford, A. Vernacular Architecture and Energy Use in Buildings: A Comparative Study. Int. J. Adv. Mech. Civ. Eng. 2015, 2, 35-42.

77. Borong, L.; Gang, T.; Peng, W.; Ling, S.; Yingxin, Z.; Guangkui, Z. Study on the Thermal Performance of the Chinese Traditional Vernacular Dwellings in Summer. Energy Build. 2004, 36, 73-79. [CrossRef]

78. Rijali, H.B.; Yoshida, H. Winter Thermal Comfort of residents in the Himalaya Region of Nepal. In Proceedings of the International Conference on Comfort and Energy Use in Buildings-Getting Them Right, Winsdor, UK, 27-30 April 2006.

79. Abdulkareem, H.A. Thermal comfort through the microclimates of the courtyard. A critical review of the middle-eastern courtyard house as a climatic response. Procedia-Soc. Behav. Sci. 2016, 216, 662-674. [CrossRef]

80. Dili, A.S.; Naseer, M.A.; Varghese, T.Z. Passive control methods of Kerala traditional architecture for a comfortable indoor environment: A comparative investigation during winter and summer. Build. Environ. 2010, 45, 1134-1143. [CrossRef]

81. Cañas, I.; Martín, S. Recovery of Spanish vernacular construction as a model of bioclimatic architecture. Build. Environ. 2004, 39, 1477-1495. [CrossRef]

82. Göçer, Ö.; Shrestha, P.; Boyacıoğlu, D.; Göçer, K.; Karahan, E. Rural Gentrification of the Ancient City of Assos (Behramkale) in Turkey. J. Rural. Stud. 2021, 87, 146-159. [CrossRef]

83. TUIK (Turkish Statistical Institute). Available online: https:/ / data.tuik.gov.tr/Kategori/GetKategori?p=nufus-ve-demografi-10 9\&dil=1 (accessed on 12 December 2020).

84. Arslan, N. The Most Perfect Idea of a Greek City: Results of New Research in Assos (Behramkale), Turkey. In The Archaeology of Anatolia, Volume III: Recent Discoveries (2017-2018); Steadman, S.R., McMahon, G., Eds.; Cambridge Scholars Publishing: Newcastle, UK, Chapter 7; pp. 139-162.

85. Serdaroglu, U. Behramkale, Assos; Archaeology and Art Publication: Istanbul, Turkey, 1995. (In Turkish)

86. Mainieri, T.; Barnett, E.G.; Valdero, T.R.; Unipan, J.B.; Oskamp, S. Green Buying: The Influence of Environmental Concern on Consumer Behavior. J. Soc. Psychol. 1997, 137, 189-204. [CrossRef]

87. Olli, E.; Grendstad, G.; Wollebaek, D. Correlates of environmental behaviors: Bringing back social context. Environ. Behav. 2001, 33, 181-208. [CrossRef]

88. Carlsson-Kanyama, A.; Lindén, A.L. Energy efficiency in residences—challenges for women and men in the North. Energy Policy 2007, 35, 2163-2172. [CrossRef]

89. Poortinga, W.; Steg, L.; Vlek, C.; Wiersma, G. Household preferences for energy-saving measures: A conjoint analysis. J. Econ. Psychol. 2003, 24, 49-64. [CrossRef]

90. Nair, G.; Gustavsson, L.; Mahapatra, K. Factors influencing energy efficiency investments in existing Swedish residential buildings. Energy Policy 2010, 38, 2956-2963. [CrossRef]

91. OECD (Organisation for Economic Co-operation and Development). Greening Household Behaviour: The Role of Public Policy; OECD: Paris, France, 2011. Available online: https:/ / www.oecd.org/env/consumption-innovation/greening-household-behaviour-20 11.htm (accessed on 23 April 2021).

92. Mills, B.; Schleich, J. Residential energy-efficient technology adoption, energy conservation, knowledge, and attitudes: An analysis of European countries. Energy Policy 2012, 49, 616-628. [CrossRef]

93. Mills, B.; Schleich, J. What's driving energy efficient appliance label awareness and purchase propensity? Energy Policy 2010, 38, 814-825. [CrossRef]

94. Pothitou, M.; Varga, L.; Kolios, A.J.; Gu, S. Linking energy behaviour, attitude and habits with environmental predisposition and knowledge. Int. J. Sustain. Energy 2017, 36, 398-414. [CrossRef]

95. Vogiatzi, C.; Gemenetzi, C.; Massou, L.; Poulopoulos, S.; Papaefthimiou, S.; Zervas, E. Energy use and saving in residential sector and occupant behavior: A case study in Athens. Energy Build. 2018, 181, 1-9. [CrossRef]

96. Gatersleben, B.; Steg, L.; Vlek, C. Measurement and Determinants of Environmentally Significant Consumer Behavior. Environ. Behav. 2002, 34, 335-362. [CrossRef]

97. Martinsson, J.; Lundqvist, L.J.; Sundstrom, A. Energy saving in Swedish households. The (relative) importance of environmental attitudes. Energy Policy 2011, 39, 5182-5191. [CrossRef]

98. Yue, T.; Long, R.; Chen, H. Factors influencing energy-saving behavior of urban households in Jiangsu Province. Energy Policy 2013, 62, 665-675. [CrossRef] 
99. Hori, S.; Kondo, K.; Nogata, D.; Ben, H. The determinants of household energy-saving behavior: Survey and comparison in five major Asian cities. Energy Policy 2013, 52, 354-362. [CrossRef]

100. Salman, M. Sustainability and vernacular architecture: Rethinking what identity is. In Urban and Architectural Heritage Conservation within Sustainability; IntechOpen: London, UK, 2018. 